\title{
Rapid synthesis of Co, Ni co-doped ZnO nanoparticles: Optical and electrochemical properties
}

\author{
Fernanda C. Romeiro ${ }^{a}$, Juliane Z. Marinho ${ }^{a}$, Samantha C.S. Lemos ${ }^{a}$, Ana P. de Moura ${ }^{b}$, \\ Poliana G. Freire ${ }^{\mathrm{a}}$, Luis F. da Silva ${ }^{\mathrm{b}}$, Elson Longo ${ }^{\mathrm{b}}$, Rodrigo A.A. Munoz ${ }^{\mathrm{a}}$, Renata C. Lima ${ }^{\mathrm{a}, *}$ \\ a Instituto de Química, Universidade Federal de Uberlândia, 38400-902 Uberlândia, MG, Brazil \\ b LIEC, Instituto de Química, Universidade Estadual Paulista, 14800-900 Araraquara, SP, Brazil
}

\section{A R T I C L E I N F O}

\section{Article history:}

Received 13 March 2015

Received in revised form

15 July 2015

Accepted 19 July 2015

Available online 20 July 2015

Keywords:

Zinc oxide

Nanoparticles

Microwave hydrothermal

Electrochemical sensor

Photoluminescence

\begin{abstract}
A B S T R A C T
We report for the first time a rapid preparation of $\mathrm{Zn}_{1-2 x} \mathrm{Co}_{x} \mathrm{Ni}_{x} \mathrm{O}$ nanoparticles via a versatile and environmentally friendly route, microwave-assisted hydrothermal (MAH) method. The Co, Ni co-doped ZnO nanoparticles present an effect on photoluminescence and electrochemical properties, exhibiting excellent electrocatalytic performance compared to undoped $\mathrm{ZnO}$ sample. Photoluminescence spectroscopy measurements indicated the reduction of the green-orange-red visible emission region after adding $\mathrm{Co}$ and $\mathrm{Ni}$ ions, revealing the formation of alternative pathways for the generated recombination. The presence of these metallic ions into $\mathrm{ZnO}$ creates different defects, contributing to a local structural disorder, as revealed by Raman spectra. Electrochemical experiments revealed that the electrocatalytic oxidation of dopamine on $\mathrm{ZnO}$ attached to multi-walled carbon nanotubes improved significantly in the $\mathrm{Co}$, Ni co-doped $\mathrm{ZnO}$ samples when compared to pure $\mathrm{ZnO}$.
\end{abstract}

(c) 2015 Elsevier Inc. All rights reserved.

\section{Introduction}

In the past decades, nano-sized materials have attracted attention owing to their interesting properties and potential application in many important fields. The properties of these materials are greatly affected by their size and shape [1,2], which generate interest in the synthesis of semiconductor nanoparticles exhibiting different shapes, such as nanobelts and nanowires [3], nanospheres [4], nanoplates [5] and nanoflowers [6], among others. Recent reviews have highlighted the potential electrochemical applications of $\mathrm{ZnO}$ attached to carbon nanotubes [7,8]. Electrochemical sensors using a combination of $\mathrm{ZnO}$ nanoparticles with carbon nanotubes presented improved characteristics, such as higher selectivity and sensitivity owing to the electrocatalytic properties of the resulting composite material, which has been demonstrated in the sensing of hydrazine [9], hydrogen peroxide [10], hydroxilamine [11], xanthine [12], and p-nitrophenol [13]. Nevertheless, few studies have been devoted to investigating the effect of doping $\mathrm{ZnO}$ attached to carbon nanotubes on electrochemical sensing performance.

Doping $\mathrm{ZnO}$ with magnetic ions is an interesting alternative to enhance ferromagnetic properties, as well as optical and electrical

\footnotetext{
* Corresponding author.

E-mail address: rclima@iqufu.ufu.br (R.C. Lima).
}

properties, which are crucial for its practical applications [14-16]. Previous works have demonstrated the influence of $\mathrm{Co}^{2+}$ and $\mathrm{Ni}^{2+}$ ion doping on the optical properties of semiconducting oxides, providing the formation of multi-emission centres in the final materials, and promoting a charge-transfer state just below the band-gap energy [17-19]. The origin of the visible emission in zinc oxide remains difficult for separating the produced emissions by different types of defects. Srinet et al.'s [20] previous work demonstrated the influence of $\mathrm{Co}^{2+}$ and $\mathrm{Ni}^{2+}$ ion doping on the optical properties of semiconducting oxides, providing the formation of multi-emission centres in the final materials, and promoting a charge-transfer state just below the band-gap energy. Sebastian et al. [21] showed that the photoluminescence (PL) emission for the $\mathrm{Co}$, Ni co-doping $\mathrm{ZnO}$ is almost quenched, indicating that $\mathrm{O}$ vacancies are filled up in the sample. On the other hand, the enhancement of PL intensity with the $\mathrm{Co}^{2+}$ doping was reported by Wang et al. [22], who attributed this result to the increase of defects and oxygen vacancies.

The microwave-assisted hydrothermal (MAH) method has been employed extensively in the preparation of organic and inorganic compounds. The advantages of MAH route are rapid and homogeneous heating, high reaction rate, short reaction time, lower cost and energy savings, when compared to a conventional hydrothermal method [23-27]. In this work Co, Ni co-doped $\mathrm{ZnO}$ powders were prepared via the MAH method, using a short reaction 
time and a low synthesis temperature. The effect of adding $\mathrm{Co}^{2+}$ and $\mathrm{Ni}^{2+}$ ions to the structural, microstructural, and optical properties of the $\mathrm{ZnO}$ was investigated using X-ray diffraction (XRD), Raman spectroscopy, scanning and transmission electron microscopy (FE-SEM and TEM), photoluminescence spectroscopy $(\mathrm{PL})$, ultraviolet-visible spectroscopy (UV-vis) and X-ray photoelectron spectroscopy (XPS). Additionally, the effect of $\mathrm{Co}^{2+}$ and $\mathrm{Ni}^{2+}$ co-doping on the electrocatalytical properties of $\mathrm{ZnO}$ attached to carbon nanotubes is presented.

\section{Experimental}

\subsection{Synthesis of $\mathrm{Co}, \mathrm{Ni}$ co-doped $\mathrm{ZnO}$ nanoparticles}

The samples were obtained from the addition of $5 \times 10^{-3} \mathrm{~mol}$ of $\mathrm{Zn}\left(\mathrm{CH}_{3} \mathrm{COO}\right)_{2}$ in $40 \mathrm{~mL}$ of distilled water under constant stirring. $\mathrm{KOH}$ solution $3 \mathrm{~mol} \mathrm{~L}^{-1}$ was added until a $\mathrm{pH}=12$ was attained. A similar procedure was employed to prepare $\mathrm{Co}^{2+}, \mathrm{Ni}^{2+}$ co-doped $\mathrm{ZnO}$ samples, with the addition of stoichiometry concentrations of $\mathrm{Co}\left(\mathrm{NO}_{3}\right)_{2} \cdot 6 \mathrm{H}_{2} \mathrm{O}$ and $\mathrm{Ni}\left(\mathrm{NO}_{3}\right)_{2} \cdot 6 \mathrm{H}_{2} \mathrm{O}$ precursors. The final solution was transferred into a Teflon autoclave, and then sealed and placed in the microwave-assisted equipment. All solutions were annealed for $8 \mathrm{~min}$ at $100{ }^{\circ} \mathrm{C}$. The precipitate powder was washed several times with deionized water and ethanol. Finally, the powder samples were dried at $60{ }^{\circ} \mathrm{C}$ for $2 \mathrm{~h}$ in an air atmosphere.

\subsection{Characterization}

$\mathrm{Zn}_{1-2 x} \mathrm{Co}_{x} \mathrm{Ni}_{x} \mathrm{O}$ samples were characterized by X-ray diffraction (Shimadzu XRD 6000) with a $\mathrm{Cu} \mathrm{K} \alpha$ radiation source. The structure was refined using the Rietveld Method and the General Structure Analysis System (GSAS) package, with an EXPGUI graphical user interface [28]. The morphological characterization was performed using a field emission scanning electron microscope (FE-SEM, Zeiss Supra35) operating at $5 \mathrm{kV}$. Transmission electron microscopy (TEM) and the micro-analysis by energy-dispersive X-ray (EDX) spectroscopy were performed on an FEI Tecnai G2F20, operating at $200 \mathrm{kV}$. UV-visible spectra of $\mathrm{Zn}_{1-2 x} \mathrm{Co}_{x} \mathrm{Ni}_{x} \mathrm{O}$ samples were obtained on a Cary 5G spectrophotometer in the 200$900 \mathrm{~nm}$ region. Raman spectra at room temperature were recorded on a RFS/100/S Bruker FT-Raman spectrometer, with a Nd: YAG laser providing an excitation light at $1064 \mathrm{~nm}$ and a spectral resolution of $4 \mathrm{~cm}^{-1}$. Photoluminescence (PL) spectra were recorded at room temperature by a thermal Jarrel-Ash Monospec 27 monochromator and a Hamamatsu R446 photomultiplier ( $\lambda_{\text {exc }}$ $=350.7 \mathrm{~nm}$ ). X-ray photoelectron spectroscopy (XPS) analyses were performed on a Thermo Scientific K-Alpha spectrometer, using a monochromatic Al K $\alpha$ X-ray source. All binding energies were referred to the C1s signal $(284.9 \mathrm{eV})$ arising from surface hydrocarbons.

\subsection{Electrochemical testing}

Electrochemical measurements were performed in a microAutolab potentiostat connected to a computer using GPES software. Cyclic voltammetry experiments were carried out in an electrochemical cell of $10 \mathrm{~mL}$ containing a three-electrode system, including a platinum wire as the counter electrode, an $\mathrm{Ag} / \mathrm{AgCl}$ (saturated $\mathrm{KCl}$ ) reference electrode and a glassy-carbon disc (1.6 mm diameter) as the working electrode. A $0.1 \mathrm{~mol} \mathrm{~L}^{-1} \mathrm{HClO}_{4}$ solution was used as the supporting electrolyte.

Multi-walled carbon nanotubes (MWCNTs, > 90\%, DxL 110$70 \mathrm{~nm} \times 5-9 \mu \mathrm{m}$ ) were purchased from Aldrich (USA). Pristine MWCNTs were sonicated in 3:1 (v/v) of concentrated $\mathrm{H}_{2} \mathrm{SO}_{4}$ and $\mathrm{HNO}_{3}$ for $3 \mathrm{~h}$, in an ultrasonic bath at $40{ }^{\circ} \mathrm{C}$, to obtain carboxylic- acid-functionalized MWCNTs. Next, doped or undoped ZnO nanoparticles $(1.5 \mathrm{mg}$ ) were attached to carboxylic-acid-functionalized MWCNTs ( $4.0 \mathrm{mg}$ ) under sonication for $3 \mathrm{~h}$ in an ultrasonic bath, and for $30 \mathrm{~min}$ under high-power sonication in acetone. An aliquot of $10 \mu \mathrm{L}$ of the suspension was dropped on an inverted glassy-carbon electrode. The electrode was covered using a clamped sample tube and the solvent was evaporated by exposure at $50{ }^{\circ} \mathrm{C}$ for $30 \mathrm{~min}$.

The electrocatalytic properties of the modified electrode towards the electrochemical oxidation of dopamine were evaluated by cyclic voltammetry. As a control, the glassy-carbon surface was also modified with MWCNTs, $\mathrm{ZnO}, \mathrm{ZnO} / \mathrm{MWCNT}$ or $\mathrm{Co}^{2+}, \mathrm{Ni}^{2+} \mathrm{Co}-$ doped $\mathrm{ZnO}$, and these modified surfaces were also applied to the electrochemical oxidation of dopamine. These materials were suspended for 30 min under high-power sonication in acetone before electrode modification.

\section{Results and discussion}

XRD patterns refined by the Rietveld method are presented in Fig. 1 . The results show that co-doped samples had a single pure phase with a wurtzite structure, hexagonal symmetry with the P63mc space group, without the formation of secondary phases. Table 1 displays the results obtained after the final cycle of refinement. The cell parameters, a and c, of the co-doped samples decrease with an increasing concentration of the dopant, which can be assigned to a smaller ionic radius of $\mathrm{Ni}^{2+}$ and $\mathrm{Co}^{2+}$ than that of the $\mathrm{Zn}^{2+}$, indicating that $\mathrm{Co}^{2+}$ and $\mathrm{Ni}^{2+}$ ions are incorporated well in the $\mathrm{ZnO}$ matrix and occupy the $\mathrm{Zn}^{2+}$ sites [20,29].

Fig. 2 shows the FE-SEM and TEM images and the histogram results of the $\mathrm{Zn}_{1-2 x} \mathrm{Co}_{x} \mathrm{Ni}_{x} \mathrm{O}$ samples. The samples where $x=0.0$ and 0.005 presented irregular elongated shapes, while the sample with $x=0.01$ exhibited uniform particle size and regular hexagonal morphology, as displayed in Fig. 2(a, c and e). The individual particles of pure and doped samples are shown in TEM images (Fig. 2(b, d and f)), which reveal well-defined hexagonal shapes with a diameter of about $45 \mathrm{~nm}$ for the sample doped with $0.01 \mathrm{~mol}$ of $\mathrm{Co}^{2+}$ and $\mathrm{Ni}^{2+}$ (Fig. 2(f)).

The EDX results, presented in Table 2, confirm the presence of cobalt and nickel ions in the $\mathrm{ZnO}$ samples. Additionally, the average particle distributions from the analysis of FE-SEM micrographs revealed the uniform growth of particle size obtained by the MAH treatment. The average particle sizes were $80 \mathrm{~nm}(x=0.0), 130 \mathrm{~nm}$ $(x=0.005)$ and $90 \mathrm{~nm}(x=0.01)$. During the microwave heating,

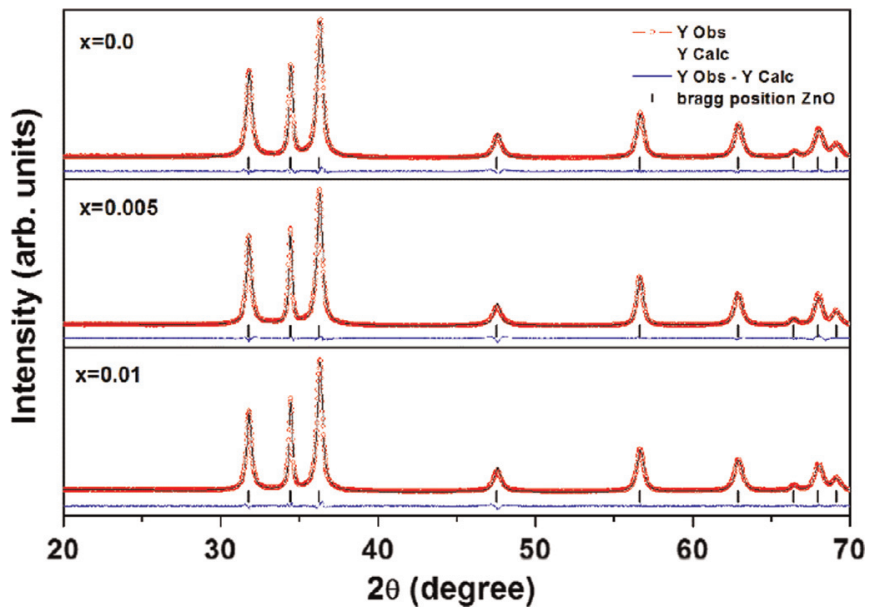

Fig. 1. Rietveld refinement plots for $\mathrm{Zn}_{1-2 x} \mathrm{Co}_{x} \mathrm{Ni}_{x} \mathrm{O}$ samples obtained by the $\mathrm{MAH}$ method, $x=\mathrm{mol}$ of $\mathrm{Co}^{2+}$ and $\mathrm{Ni}^{2+}$. 
Table 1

Parameters obtained from Rietveld refinement of $\mathrm{Zn}_{1-2 x} \mathrm{Co}_{x} \mathrm{Ni}_{x} \mathrm{O}$ samples $\left(x=\right.$ mol of $\mathrm{Co}^{2+}$ and $\left.\mathrm{Ni}^{2+}\right)$.

\begin{tabular}{|c|c|c|c|c|c|c|c|}
\hline \multirow[t]{2}{*}{ Samples $(x)$} & \multicolumn{3}{|c|}{ Cell parameteres } & \multirow[t]{2}{*}{$R_{\mathrm{wp}}(\%)$} & \multirow[t]{2}{*}{$R_{\mathrm{p}}(\%)$} & \multirow[t]{2}{*}{$R_{\text {bragg }}(\%)$} & \multirow[t]{2}{*}{$\chi^{2}$} \\
\hline & $a(\AA)$ & $c(\AA)$ & $V\left(\AA^{3}\right)$ & & & & \\
\hline 0.0 & $3.2512(3)$ & $5.2114(5)$ & $47.706(12)$ & 4.79 & 3.48 & 0.56 & 1.61 \\
\hline 0.005 & $3.2510(1)$ & $5.2113(3)$ & $47.698(8)$ & 6.34 & 4.45 & 1.83 & 2.85 \\
\hline 0.01 & $3.2509(3)$ & $5.2112(4)$ & 47.696(12) & 5.20 & 3.77 & 1.30 & 1.93 \\
\hline
\end{tabular}

clusters were formed by collision and rearrangement of atoms, and growth proceeded by nucleation of nanoparticles to larger dimensions [30]. Their spontaneous associations to form larger particles, the fast disjunction allow different stages of zinc oxide growth to be obtained, and the heating method are factors, which can greatly influence the morphology of the particles [31]. Furthermore, the fast heating under microwave hydrothermal conditions provides a great mobility for dissolved ions and molecules, accelerating the solid particles at high speeds, and consequently providing an increased collision rate and increased kinetic energy throughout the synthesis process [32-34].

The surface structure of the $\mathrm{Zn}_{1-2 x} \mathrm{Co}_{x} \mathrm{Ni}_{x} \mathrm{O}$ samples was investigated by XPS, and the corresponding experimental results are shown in Fig. 3. In Fig. 3(a), all of the peaks on the curve are ascribed to $\mathrm{Zn}, \mathrm{Co}, \mathrm{Ni}, \mathrm{O}$, and $\mathrm{C}$ elements, and no peaks of other elements are observed. The high-resolution XPS spectra of $\mathrm{Zn} 2 \mathrm{p}$, Co 2p, Ni 2p, and $\mathrm{O}$ 1s are shown in Fig. 3(b-e), respectively. The Zn 2p peaks appearing in Fig. 3(b) are symmetric and centred at approximately $1021.3 \mathrm{eV}$ and $1044.4 \mathrm{eV}$, which are consistent with the values reported for $\mathrm{Zn}^{2+}$ [35]. The Co 2p spectra (Fig. 3(c)) show four peaks: $2 \mathrm{p}_{3 / 2}$ at approximately $780.6 \mathrm{eV}$; and $2 \mathrm{p}_{1 / 2}$ at 796.4 doublet. The shake-up resonance transitions (satellite) of
Table 2

EDX data of the $\mathrm{Zn}_{1-2 x} \mathrm{Co}_{x} \mathrm{Ni}_{x} \mathrm{O}$ samples $\left(x=\mathrm{mol} \%\right.$ of $\mathrm{Co}^{2+}$ and $\left.\mathrm{Ni}^{2+}\right)$.

\begin{tabular}{lrr}
\hline Element & $\begin{array}{c}x=0.5 \\
\text { Atom \% }\end{array}$ & $\begin{array}{r}x=1.0 \\
\text { Atom \% }\end{array}$ \\
\hline O K & 35.86 & 36.49 \\
Co K & 0.47 & 0.90 \\
Ni K & 0.33 & 0.69 \\
Zn K & 63.35 & 61.91 \\
Total & 100.00 & 100.00 \\
\hline
\end{tabular}

these two peaks are at slightly higher energies. The position of the satellite peak at about $785.4 \mathrm{eV}$ is considered a feature of $\mathrm{Co}^{2+}$ ion energy [36]. Additionally, the energy difference of $15.7 \mathrm{eV}$ between Co $2 \mathrm{p}_{3 / 2}$ and Co $2 \mathrm{p}_{1 / 2}$ was assigned to divalent cobalt ions, $\mathrm{Co}^{2+}$ [36]. In Fig. 3(d), the peaks centred at around $855.4 \mathrm{eV}$ and $872.8 \mathrm{eV}$ are ascribed to $\mathrm{Ni} 2 \mathrm{p}_{3 / 2}$ and $\mathrm{Ni} 2 \mathrm{p}_{1 / 2}$, respectively. These peaks' positions are characteristic of divalent nickel ions, indicating that the $\mathrm{Ni}$ ions in $\mathrm{Zn}_{1-2 x} \mathrm{Co}_{x} \mathrm{Ni}_{x} \mathrm{O}$ samples are present as $\mathrm{Ni}^{2+}$ [37]. Furthermore, an analysis of the $\mathrm{O} 1 \mathrm{~s}$ peak shows that it can be deconvoluted into three Gaussian-Lorentzian curves, as displayed in Fig. 3(e). The lower energy peak located at around $529.7 \mathrm{eV}$
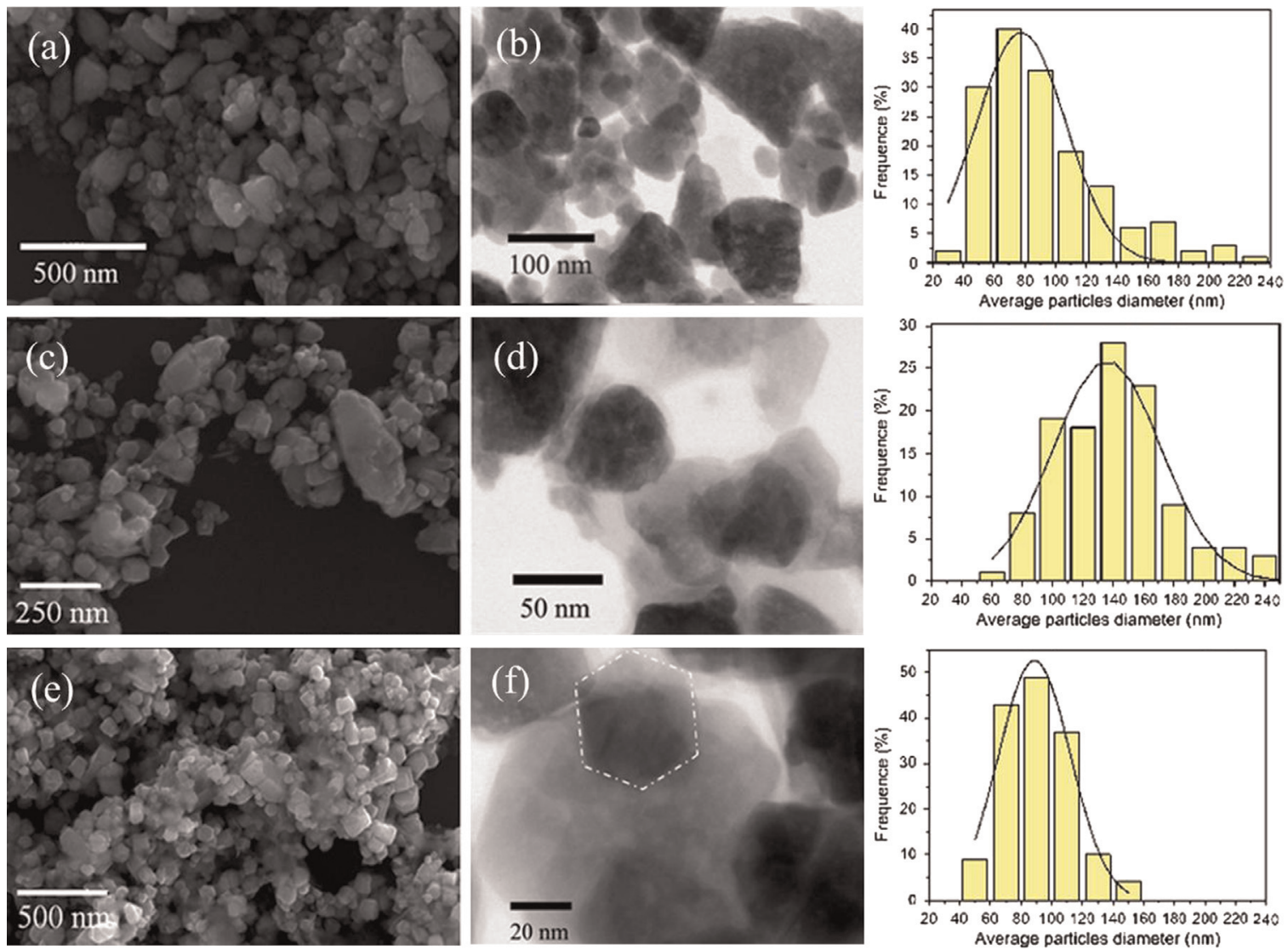

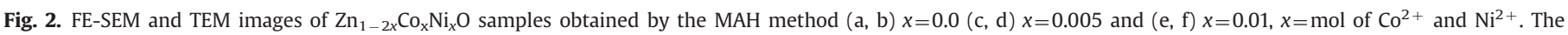
histograms on the right side of the figure correspond to the FE-SEM images to the left of them. 
a

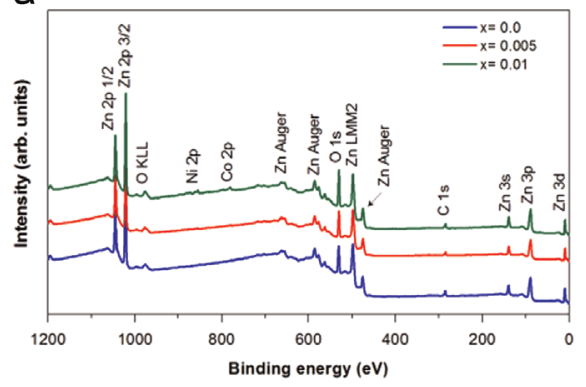

b

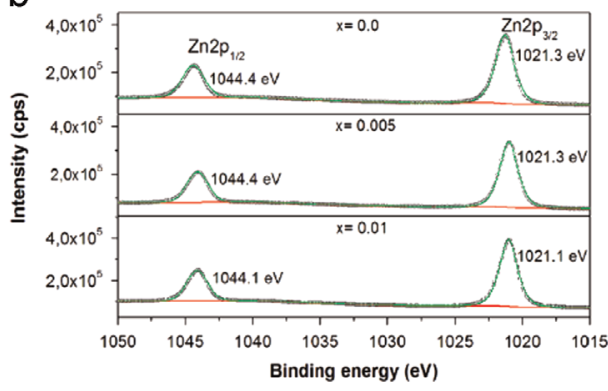

C

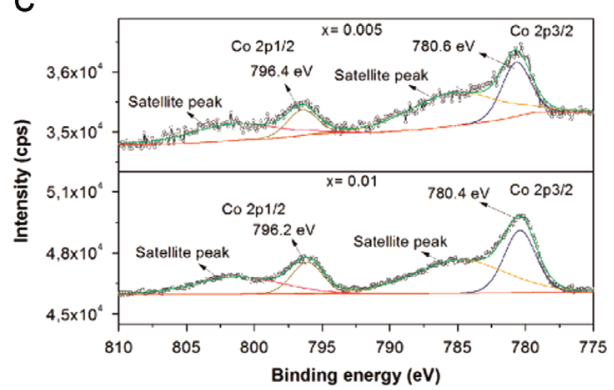

d

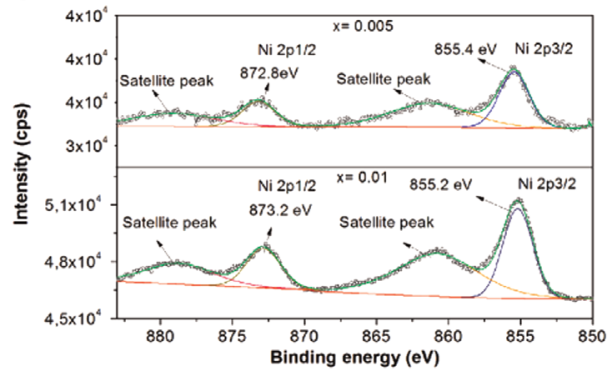

e

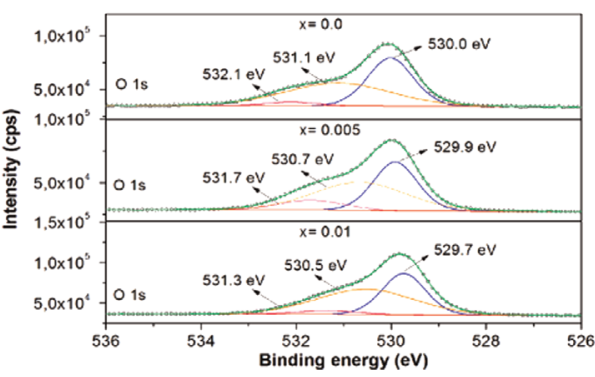

Fig. 3. XPS spectra of $\mathrm{Zn}_{1-2 x} \mathrm{Co}_{x} \mathrm{Ni}_{x} \mathrm{O}$ samples. (a) XPS survey scan spectra, (b) Zn 2p, (c) Co 2p, (d) Ni 2p, and (e) O 1s core levels.

corresponds to $\mathrm{O}^{2-}$ ions in the $\mathrm{ZnO}$ lattice, while the second peak, at approximately $530.5 \mathrm{eV}$, can be attributed to oxygen-deficient regions in the $\mathrm{ZnO}$ network [38]. The third peak has been attributed to $\mathrm{OH}$ species in $\mathrm{H}_{2} \mathrm{O}$ molecules, respectively [35,39]. These results confirm that $\mathrm{Co}^{2+}$ and $\mathrm{Ni}^{2+}$ ions were incorporated homogeneously into the $\mathrm{ZnO}$ network and that solid solutions were formed.

Fig. 4 depicts the UV-visible spectra of the undoped and doped samples. Three spin allowed transitions are expected for the electronic $\mathrm{d}^{7}$ configuration of $\mathrm{Co}^{2+}$ in tetrahedral crystal field, two bands in the infrared attributed to ${ }^{4} \mathrm{~A}_{2} \rightarrow{ }^{4} \mathrm{~T}_{2}(\mathrm{~F})$ and ${ }^{4} \mathrm{~A}_{2} \rightarrow{ }^{4} \mathrm{~T}_{1}(\mathrm{~F})$, and a most intense absorption $\left({ }^{4} \mathrm{~A}_{2} \rightarrow{ }^{4} \mathrm{~T}_{1}(\mathrm{P})\right)$ located in the visible region [40]. The $\mathrm{Co}, \mathrm{Ni}$ co-doped $\mathrm{ZnO}$ samples presented a triply splitted bands centred at 563, 608, and $656 \mathrm{~nm}$ assigned to the spin allowed electronic transition ${ }^{4} \mathrm{~A}_{2} \rightarrow{ }^{4} \mathrm{~T}_{1}(\mathrm{P})$ of $\mathrm{Co}^{2+}$ owing to a distorted tetrahedron, or to spin-orbit coupling. A weak absorption band in the $660 \mathrm{~nm}$ range covered by the $\mathrm{Co}^{2+}$ bands is characteristic of $\mathrm{Ni}^{2+}$ ion transitions in tetrahedral coordination in

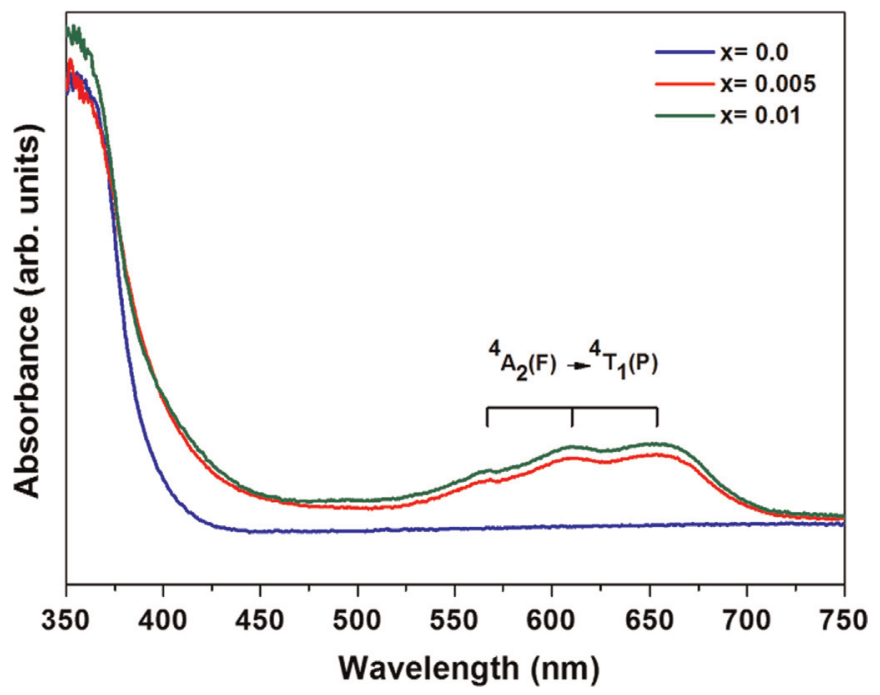

Fig. 4. Optical absorbance spectra of $\mathrm{Zn}_{1-2 x} \mathrm{Co}_{x} \mathrm{Ni}_{x} \mathrm{O}$ samples obtained by the $\mathrm{MAH}$ method, $x=$ mol of $\mathrm{Co}^{2+}$ and $\mathrm{Ni}^{2+}$.

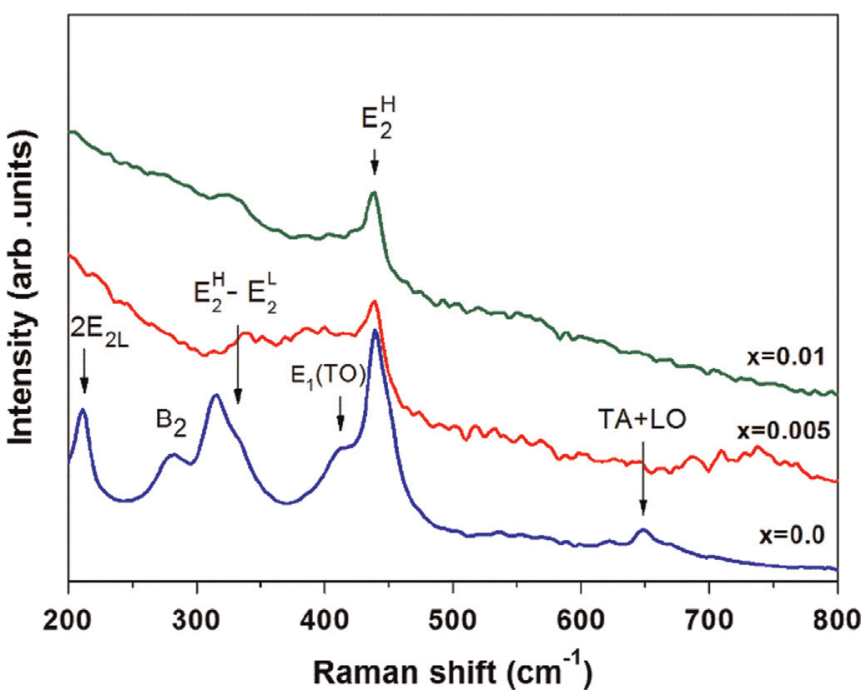

Fig. 5. Raman spectra of $\mathrm{Zn}_{1-2 x} \mathrm{Co}_{x} \mathrm{Ni}_{x} \mathrm{O}$ samples obtained by the MAH method, $x=$ mol of $\mathrm{Co}^{2+}$ and $\mathrm{Ni}^{2+}$.

the $\mathrm{ZnO}$ wurtzite structure [41].

Raman spectra of $\mathrm{Zn}_{1-2 x} \mathrm{Co}_{x} \mathrm{Ni}_{x} \mathrm{O}$ samples obtained by the $\mathrm{MAH}$ method are shown in Fig. 5. All the samples presented a peak at around $438 \mathrm{~cm}^{-1}$ corresponding to $\mathrm{E}_{2}$ (high) mode, which is characteristic of the wurtzite structure [25]. The Raman modes at 332 and $411 \mathrm{~cm}^{-1}$ are ascribed to $3 \mathrm{E}_{2 \mathrm{H}}-\mathrm{E}_{2 \mathrm{~L}}$ and $\mathrm{E}_{1}(\mathrm{TO})$ phonon modes, also belonging to $\mathrm{ZnO}$. The band located at $650 \mathrm{~cm}^{-1}$ $(\mathrm{TA}+\mathrm{LO})$ refers to multi-phonon modes in $\mathrm{ZnO}[25,42]$. In a previous work, Calleja et al. attributed the peak at $280 \mathrm{~cm}^{-1}$ resulting from the phonon dispersion curves of single crystalline $\mathrm{ZnO}$ to activation of the silent $B_{2}$ mode [43]. The strong peak at $210 \mathrm{~cm}^{-1}$ referring to the $2 \mathrm{E}_{2 \mathrm{~L}}$ second-order phonon mode emerged [44]. The $E_{2 H}$ modes became weak with the incorporation of metallic ions into the host matrix, which can be attributed to structural defect formation and local distortions induced by doping [14,45]. Additionally, any additional Raman modes associated with the presence of secondary phases were observed, in good accordance with XRD results. 


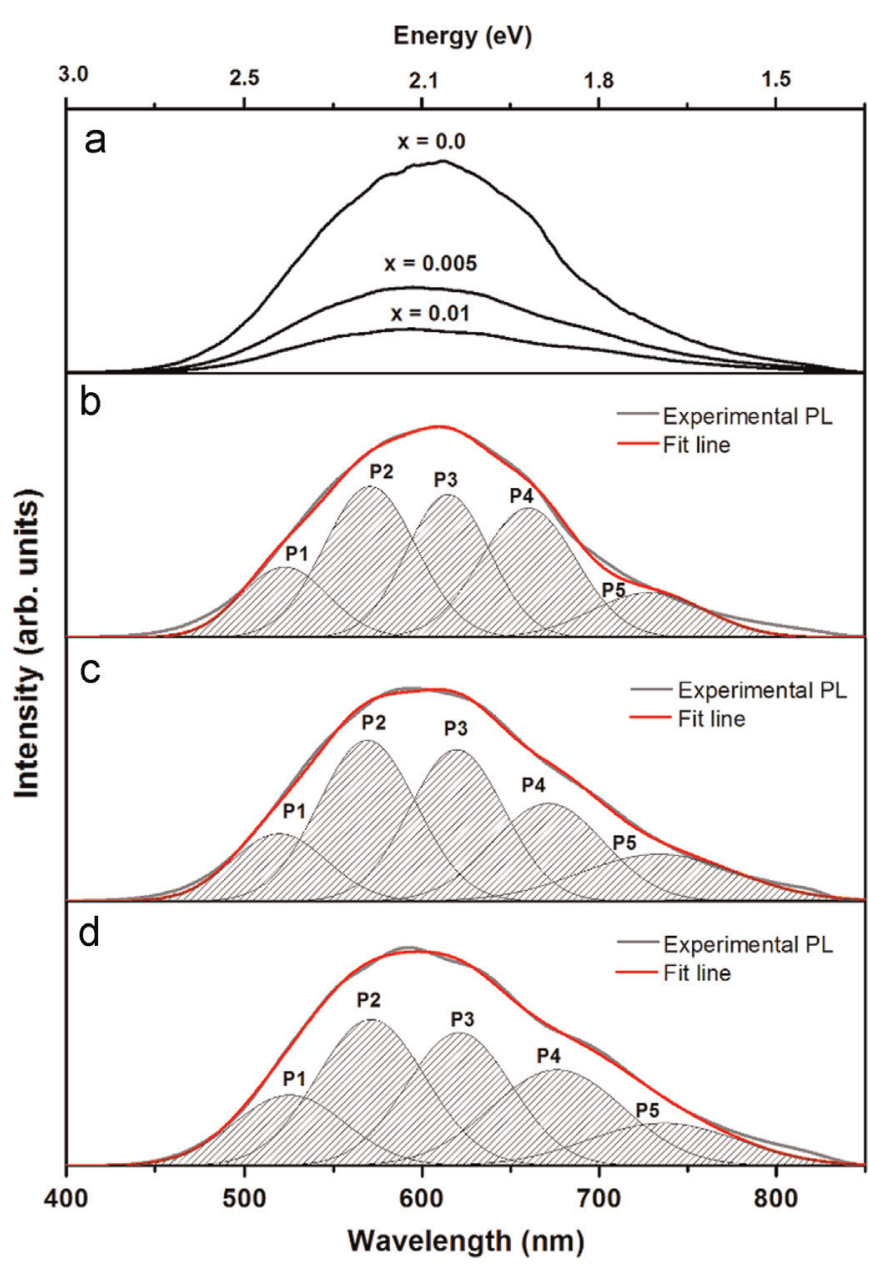

Fig. 6. PL spectra of $\mathrm{Zn}_{1-2 x} \mathrm{Co}_{x} \mathrm{Ni}_{x} \mathrm{O}$ samples prepared by the MAH method, $x=$ mol of $\mathrm{Co}^{2+}$ and $\mathrm{Ni}^{2+}$ (a). Deconvoluted PL curves results (b) $x=0.0$ (c) $x=0.005$ and (d) $x=0.01$.

Fig. 6(a) exhibits the photoluminescence (PL) spectra of $\mathrm{Zn}_{1-2 x} \mathrm{Co}_{x} \mathrm{Ni}_{x} \mathrm{O}$ samples prepared by the MAH method. The PL emission intensity is sensitive to different types of defects generated in solution during $\mathrm{ZnO}$ nanoparticle growth under $\mathrm{MAH}$ conditions, as reported by Lima et al. [25,46]. Similar effects were also reported by Romeiro et al. [15], who attributed the PL intensity to the incorporation of $\mathrm{Mn}^{2+}$ ions in the $\mathrm{ZnO}$ network, which increased the density of structural imperfections. These contributed to energy uptake at the lower levels of the conduction band, leading to high structural disorder at the short range of the doped samples. Bohle et al. [47] reported that optimal PL quenching correlated with the end of nucleation of undoped $\mathrm{ZnO}$ nanocrystals, indicating that the ideal time of $\mathrm{Co}^{2+}$ addition was related to the growth process of $\mathrm{ZnO}$ nanocrystals. Additionally, the incorporated ions can promote stress in the $\mathrm{ZnO}$ structure, leading to a crystallinity decrease.

PL curves were deconvoluted into five components using the

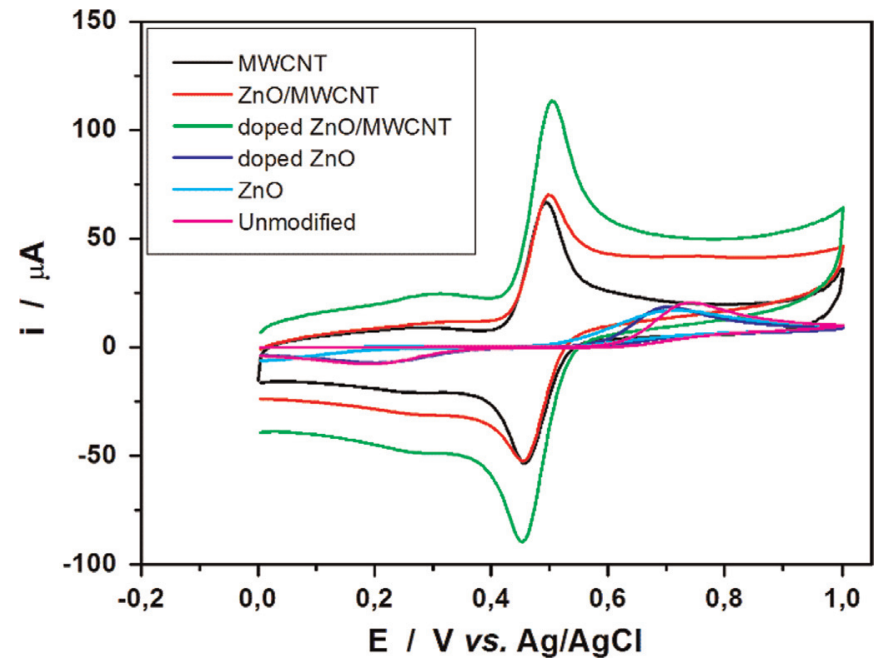

Fig. 7. Cyclic voltammograms for $1 \mathrm{mmol} \mathrm{L}^{-1}$ dopamine at unmodified glassycarbon electrode and after modification with MWCNT, ZnO, ZnO/MWCNT, $\mathrm{Zn}_{1-2 x} \mathrm{Co}$ ${ }_{x} \mathrm{Ni}_{x} \mathrm{O}$, and $\mathrm{Zn}_{1-2 x} \mathrm{Co}_{x} \mathrm{Ni}_{x} \mathrm{O} / \mathrm{MWCNT}$. Electrolyte: $0.1 \mathrm{~mol} \mathrm{~L}^{-1} \mathrm{HClO}_{4}$; scan rate of $50 \mathrm{mV} \mathrm{s}^{-1}, x=0.01 \mathrm{~mol}$ of $\mathrm{Co}^{2+}$ and $\mathrm{Ni}^{2+}$.

Gaussian method and the Peak Fit program: two green components (maximum at 520 and $567 \mathrm{~nm}$ ), an orange component (maximum at $620 \mathrm{~nm}$ ) and two red components (maximum at 673 and $730 \mathrm{~nm}$ ). Fig. 6(b)-(d) displays the PL spectra and the corresponding deconvoluted curves, while Table 3 shows the area data under each curve of respective transitions. Each region represents a different type of electronic transition and can be linked to different types of defects $[25,48]$. Green emission is the most commonly observed defect emission in $\mathrm{ZnO}$ nanostructures, which can be attributed to singly oxygen vacancies [49-52], while orangered emissions can be attributed to oxygen interstitials [53-55].

The modification of surfaces with ZnO attached to MWCNTs has been applied successfully to develop improved electrochemical sensors. Thus, the effect of $\mathrm{Co}^{2+}, \mathrm{Ni}^{2+}$ co-doping in the $\mathrm{ZnO}$ nanoparticles was evaluated towards the electrochemical oxidation of dopamine, which is a relevant neurotransmitter in brain chemistry. Cyclic voltammetry of the glassy-carbon electrode before and after modification with $\mathrm{Co}^{2+}, \mathrm{Ni}^{2+}$ co-doped $\mathrm{ZnO}$, attached to MWNCTs in the presence of dopamine, is presented in Fig. 7. As a control, cyclic voltammograms of the unmodified and modified glassy-carbon electrode with MWCNTs, ZnO, co-doped $\mathrm{ZnO}$, and $\mathrm{ZnO}$ attached to MWCNTs (ZnO/MWCNTs), in the presence of dopamine under the same conditions, are also presented in the same figure.

The electrochemical oxidation of dopamine undergoes a quasireversible process involving a two-electron transfer through the formation of a quinone derivative molecule. The cyclic voltammogram performed at the bare glassy-carbon surface shows the electrochemical oxidation of dopamine, starting at $0.6 \mathrm{~V}$ with an oxidation peak at $0.7 \mathrm{~V}$ and a reduction peak occurring at $0.2 \mathrm{~V}$ (peak-to-peak separation of $500 \mathrm{mV}$ ). Similar electrochemical behaviour was observed at the electrode modified with $\mathrm{ZnO}$ and $\mathrm{Co}^{2+}, \mathrm{Ni}^{2+}$ co-doped $\mathrm{ZnO}$, which indicates that $\mathrm{ZnO}$ nanoparticles

Table 3

Fitting parameters of the photoluminescence spectra of $\mathrm{Zn}_{1-2 x} \mathrm{Co}_{x} \mathrm{Ni}_{x} \mathrm{O}$ samples $\left(x=\right.$ mol of $\mathrm{Co}^{2+}$ and $\left.\mathrm{Ni}^{2+}\right)$.

\begin{tabular}{|c|c|c|c|c|c|}
\hline \multirow[t]{2}{*}{ Samples $(x)$} & \multicolumn{5}{|l|}{$\%$ Area } \\
\hline & P1 (520 nm) & P2 (567 nm) & P3 (620 nm) & P4 (673 nm) & P5 $(730 \mathrm{~nm})$ \\
\hline 0.0 & 13.4 & 29.2 & 25.7 & 20.0 & 11.7 \\
\hline 0.005 & 11.6 & 28.8 & 26.3 & 19.9 & 13.4 \\
\hline 0.01 & 13.8 & 28.0 & 24.7 & 22.3 & 11.2 \\
\hline
\end{tabular}


did not affect the electro-oxidation of dopamine. As expected, MWCNTs present an electrocatalytic effect towards the oxidation of dopamine [56], which can be verified by the significant decrease in peak-to-peak separation $(50 \mathrm{mV})$ and the increase (3-fold) in redox current. The attachment of $\mathrm{ZnO}$ to MWCNTs did not provide any improvement in the electrochemical oxidation of dopamine, as the resulting cyclic voltammetry presented a similar profile to the one registered at the MWCNTs-modified surface. On the other hand, the modified electrode with the $\mathrm{ZnO}$ doped with $0.01 \mathrm{~mol}$ of $\mathrm{Co}^{2+}$ and $\mathrm{Ni}^{2+}$ attached to MWCNTs produced a significantly higher current for dopamine oxidation, in comparison with MWCNTs- and ZnO/MWCNTs-modified electrodes. The peak-topeak separation was constant $(50 \mathrm{mV})$, however, the current increased almost twice (faradaic current responsible for the electrochemical oxidation of dopamine subtracted from baseline) and the oxidation/reduction current ratio was closer to unity, which is another indication of electrochemical reversibility attained as a result of the electrocatalytic effect of the modified electrode. Thus, this result demonstrated that the $\mathrm{Co}^{2+}, \mathrm{Ni}^{2+}$ co-doping in the $\mathrm{ZnO}$ structure affected its synergistic electrocatalytic activity when attached to MWCNTs. A similar result was presented for the electrochemical oxidation of dopamine, using a NiO-MWCNT composite [57]. This synergistic effect is possible since the nickel and cobalt oxides are reported to be effective catalysts for many electrochemical reactions [57-59].

\section{Conclusions}

In summary, $\mathrm{Zn}_{1-2 x} \mathrm{Co}_{x} \mathrm{Ni}_{x} \mathrm{O}$ nanoparticles were synthesized successfully using the MAH method at low temperature and a short treatment time. XPS analysis revealed the presence of $\mathrm{Co}^{2+}$ and $\mathrm{Ni}^{2+}$ in a tetrahedral configuration, indicating that the divalent ions were incorporated homogeneously into the $\mathrm{ZnO}$ network, as observed by the XRD analyses and UV-vis spectra. The addition of $\mathrm{Co}^{2+}$ and $\mathrm{Ni}^{2+}$ ions into the $\mathrm{ZnO}$ lattice creates local defects, affecting the Raman modes, as well as the optical and electrochemical properties. The $\mathrm{Zn}_{1-2 x} \mathrm{Co}_{x} \mathrm{Ni}_{x} \mathrm{O}$ samples exhibited regular morphology with a hexagonal shape and average particle size ranging between 80 and $130 \mathrm{~nm}$, depending on the Co and $\mathrm{Ni}$ content. The broad PL emission band in the green-orange-red region decreased considerably after adding metallic ions, causing the creation of new recombination centres. The $\mathrm{Co}$, Ni co-doped $\mathrm{ZnO}$ attached to MWCNTs provided more intense electrocatalytic activity towards the oxidation of dopamine, in comparison with undoped $\mathrm{ZnO}$ attached to MWCNTs and with bare MWNCTs, which indicates that the insertion of $\mathrm{Co}^{2+}$ and $\mathrm{Ni}^{2+}$ into the oxide lattice is a potential strategy to improve selectivity and sensitivity of electrochemical sensors based on $\mathrm{ZnO}$ nanoparticles. The method enables reactions to be performed under mild reaction conditions, in shorter reaction times. In addition, the method offers the simple, clean and efficient synthesis of high-quality solid particles with controlled morphology and size. These findings demonstrate that $\mathrm{Zn}_{1-2 x} \mathrm{Co}_{x} \mathrm{Ni}_{x} \mathrm{O}$ nanoparticles can be considered promising candidates for optical devices, catalysts, solar cells, magnetic materials or electrochemical sensors.

\section{Acknowledgements}

The authors are grateful to Coordenação de Aperfeiçoamento de Pessoal de Nível Superior (Capes), Conselho Nacional de Desenvolvimento Científico e Tecnológico (CNPq), Fundação de Amparo à Pesquisa do Estado de Minas Gerais (FAPEMIG, under Grant no. APQ-00988-13), and Rede Mineira de Química (RQ-MG)
(FAPEMIG Project CEX - RED-00010-14) for the financial support. This research was partially performed at the Brazilian Nanotechnology National Laboratory, LNNano, (Project XPS-18304), Campinas, SP, Brazil.

\section{References}

[1] H.L. Xu, W.Z. Wang, W. Zhu, J. Phys. Chem. B 110 (2006) 13829-13834.

[2] M.A. El-Sayed, Acc. Chem. Res. 34 (2001) 257-264.

[3] X. Wang, J. Song, Z.L. Wang, J. Mater. Chem. 17 (2007) 711-720.

[4] Y.Z. Zhang, J. Chung, J. Lee, J. Myoung, S. Lim, J. Phys. Chem. Solids 72 (2011) 1548-1553.

[5] Y.C. Qiu, W. Chen, S.H. Yang, J. Mater. Chem. 20 (2010) 1001-1006.

[6] Y.X. Wang, X.Y. Li, N. Wang, X. Quan, Y.Y. Chen, Sep. Purif. Technol. 62 (2008) $727-732$.

[7] F. Banhart, Nanoscale 1 (2009) 201-213.

[8] X.G. Hu, S.J. Dong, J. Mater. Chem. 18 (2008) 1279-1295.

[9] K.N. Han, C.A. Li, M.P.N. Bui, X.H. Pham, G.H. Seong, Chem. Commun. 47 (2011) 938-940 47 (2011)

[10] M.B. Wayu, R.T. Spidle, T. Devkota, A.K. Deb, R.K. Delong, K.C. Ghosh, A K. Wanekaya, C.C. Chusuei, Electrochim. Acta 97 (2013) 99-104.

[11] C.H. Zhang, G.F. Wang, M. Liu, Y.H. Feng, Z.D. Zhang, B. Fang, Electrochim. Acta 55 (2010) 2835-2840.

[12] R. Devi, S. Yadav, C.S. Pundir, Analyst 137 (2012) 754-759.

[13] Y.F. Hu, Z.H. Zhang, H.B. Zhang, L.J. Luo, S.Z. Yao, Thin Solid Films 520 (2012) 5314-5321.

[14] Y.Y. Rao, H.Y. Xu, Y. Liang, S. Hark, CrystEngComm 13 (2011) 2566-2570.

[15] F.C. Romeiro, J.Z. Marinho, A.C.A. Silva, N.F. Cano, N.O. Dantas, R.C. Lima, J. Phys Chem. C 117 (2013) 26222-26227.

[16] S.B. Shi, Y. Yang, J.P. Xu, L. Li, X.S. Zhang, G.H. Hu, Z.M. Dang, J. Alloy. Compd. 576 (2013) 59-65.

[17] B. Panigrahy, M. Aslam, D. Bahadur, J. Phys. Chem. C 114 (2010) 11758-11763.

[18] T. Al-Harbi, J. Alloy. Compd. 509 (2011) 387-390.

[19] K.R. Kittilstved, W.K. Liu, D.R. Gamelin, Nat. Mater. 5 (2006) 291-297.

[20] G. Srinet, R. Kumar, V. Sajal, J. Appl. Phys. 114 (2013) 033912-033917.

[21] K.C. Sebastian, M. Chawda, L. Jonny, D. Bodas, Mater. Lett. 64 (2010) 2269-2272.

[22] B. Wang, C. Xia, J. Iqbal, N. Tang, Z. Sun, Y. Lv, L. Wu, Solid State Sci. 11 (2009) 1419-1422.

[23] V.D. Araujo, W. Avansi, H.B. de Carvalho, M.L. Moreira, E. Longo, C. Ribeiro, M.I B. Bernardi, CrystEngComm 14 (2012) 1150-1154.

[24] N. Moloto, S. Mpelane, L.M. Sikhwivhilu, S.S. Ray, Int. J. Photoenergy 2012 (2012) 1-6.

[25] R.C. Lima, L.R. Macario, J.W.M. Espinosa, V.M. Longo, R. Erlo, N.L. Marana, J. R. Sambrano, M.L. dos Santos, A.P. Moura, P.S. Pizani, J. Andres, E. Longo, J. A. Varela, J. Phys. Chem. A 112 (2008) 8970-8978.

[26] J.Z. Marinho, F.C. Romeiro, S.C.S. Lemos, F.V. Motta, C.S. Riccardi, M.S. Li, E. Longo, R.C. Lima, J. Nanomater. 2012 (2012) 1-7.

[27] H.E. Wang, L.J. Xi, R.G. Ma, Z.G. Lu, C.Y. Chung, I. Bello, J.A. Zapien, J. Solid State Chem. 190 (2012) 104-110.

[28] A.C. Larson, R.B. Von dreele, General structure analysis system, Los Alamos National Laboratory Report LAUR, 86, 2004.

[29] R.K. Singhal, A. Samariya, Y.T. Xing, S. Kumar, S.N. Dolia, U.P. Deshpande, T. Shripathi, E.B. Saitovitch, J. Alloys Compd. 496 (2010) 324-330.

[30] I. Bilecka, M. Niederberge, Nanoscale 2 (2010) 1269-1528.

[31] R.Y. Zhang, A. Khalizov, L. Wang, M. Hu, W. Xu, Chem. Rev. 112 (2012) 1957-2011.

[32] M.L. Moreira, G.P. Mambrini, D.P. Volanti, E.R. Leite, M.O. Orlandi, P.S. Pizani, V. R. Mastelaro, C.O. Paiva-Santos, E. Longo, J.A. Varela, Chem. Mater. 20 (2008) 5381-5387.

[33] Z. Wang, J.Y. Zhu, W.F. Xu, J. Sui, H. Peng, X.D. Tang, Mater. Chem. Phys. 135 (2012) 330-333.

[34] L.A. Ghule, B.S. Shirke, K.B. Sapnar, S.D. Dhole, P.P. Hankare, K.M. Garadkar, J Mater. Sci: Mater. Electron. 22 (2011) 1120-1123.

[35] J. Liu, X. Li, L. Dai., Adv. Mater. 18 (2006) 1740-1744.

[36] S. Wang, B. Zhang, C. Zhao, S. Li, M. Zhang, L. Yan., Appl. Surf. Sci. 257 (2011) 3358-3362.

[37] J. Wang, S. Fan, Y. Luan, J. Tang, Z. Jin, M. Yang, Y. Lu, RSC Adv. 5 (2015) 2405-2410.

[38] K.C. Barick, M. Aslam, D. Bahadur, J. Alloy. Compd. 587 (2014) 282-286.

[39] J. Tang, J. Chai, J. Huang, L. Deng, X.S. Nguyen, L. Sun, T. Venkatesan, Z. Shen, C. B. Tay, S.J. Chua, ACS Appl. Mater. Interfaces, 7, (2015) 4737-4743.

[40] M. Llusar, A. Forés, J.A. Badenes, J. Calbo, M.A. Tena, G.J. Monrós, Eur. Ceram. Soc 21 (2001) 1121-1130.

[41] R. Elilarassi, G. Chandrasekaran, Mater. Chem. Phys. 123 (2010) 450-455.

[42] T.L. Phan, R. Vincent, D. Cherns, N.H. Dan, S.C. Yu, Appl. Phys. Lett. 93 (2008) 082110-082113.

[43] J.M. Calleja, M. Cardona, Phys. Rev. B 16 (1977) 3753-3761.

[44] R.S. Zeferino, M.B. Flores, U. Pal, J. Appl. Phys. 109 (2011) 014308-014313.

[45] A. Singhal, S.N. Achary, J. Manjanna, S. Chatterjee, P. Ayyub, A.K. Tyagi, J. Phys. Chem C 114 (2010) 3422-3430.

[46] A.P. de Moura, R.C. Lima, M.L. Moreira, D.P. Volanti, J.W.M. Espinosa, M. 
O. Orlandi, P.S. Pizani, J.A. Varela, E. Longo, Solid State Ionics 181 (2010) 775-780.

[47] D.S. Bohle, C.J. Spina, J. Phys. Chem. C 114 (2010) 18139-18145.

[48] R. Elilarassi, G. Chandrasekaran, Mater. Sci. Semicond. Process. 14 (2011) 179-183.

[49] C. Drouilly, J.M. Krafft, F. Averseng, S. Casale, D. Bazer-Bachi, C. Chizallet, V. Lecocq, H. Vezin, H. Lauron-Pernot, G. Costentin, J. Phys. Chem. C 116 (2012) 21297-21307.

[50] X.Q. Meng, D.Z. Shen, J.Y. Zhang, D.X. Zhao, Y.M. Lu, L. Dong, Z.Z. Zhang, Y. C. Liu, X.W. Fan, Solid State Commun. 135 (2005) 179-182.

[51] C.L. Wu, X.H. Qiao, L. Luo, H.J. Li, Mater. Res. Bull. 43 (2008) 1883-1891.

[52] P. Li, S. Wang, J.B. Li, Y. Wei, J. Lumin. 132 (2012) 220-225.

[53] X. Liu, X.H. Wu, H. Cao, R.P.H. Chang, J. Appl. Phys. 95 (2004) 3141-3147.
[54] L.M. Kukreja, P. Misra, J. Fallert, D.M. Phase, H. Kalt, J. Appl. Phys. 112 (2012) $013525-013534$.

[55] A.Y.L. Sim, G.K.L. Goh, S. Tripathy, D. Andeen, F.F. Lange, Electrochim. Acta 52 (2007) 2933-2937.

[56] M.N. Zhang, K.P. Gong, H.W. Zhang, L.Q. Mao, Biosens. Bioelectron. 20 (2005) 1270-1276.

[57] L.C.S. Figueiredo-Filho, T.A. Silva, F.C. Vicentini, O. Fatibello-Filho, Analyst 139 (2014) 2842-2849.

[58] Z. Savari, S. Soltanian, A. Noorbakhsh, A. Salimi, M. Najafi, P. Servati, Sens. Actuators B 176 (2013) 335-343.

[59] A. Salimi, A. Noorbakhsh, H.-A. Rafiee-Pour, H. Ghourchian, Electroanalysis 23 (2011) 683-691. 